\title{
Chemical composition of clupeids fish as alternative replacement for foreign fish meal in fish feeds in West Africa region
}

\author{
Ibiyo $\mathrm{LMO}^{1 *}$, Kayode $\mathrm{RMO}^{2}$, Oresegun $\mathrm{A}^{3}$, Olugbenga $\mathrm{BO}^{1}$ and Joshua $\mathrm{FO}^{1}$ \\ ${ }^{1}$ Fish Nutrition and Health Programme, National Institute for Freshwater Fisheries Research, PMB, New Bussa, Niger State, Nigeria \\ ${ }^{2}$ University of Ilorin, Ilorin, Kwara State, Nigeria \\ ${ }^{3}$ Nigerian institute for oceanography and marine research (NIOMR), 3-Wilmot point road, Victoria Island, Lagos, Nigeria
}

\begin{abstract}
Sun dried Clupeids fish was acquired from fishermen in Kainji Dam Basin and Danish fish meal also procured in order to compare their nutrient composition. The clupeids fish were milled into fish meal as Danish fish meal and both were analysed for chemical composition to determine the nutrient profile using standard procedures. The results of proximate composition showed that Clupeids fish meal has $70.68 \%$ crude protein while Danish fish meal has $72.6 \%$ crude protein which were not significantly different $(\mathrm{P}>0.05)$. The results of amino acid profile analysis showed that they both contain all the essential amino acids $(\mathrm{EAA})$ and methionine and cysteine in clupeids fish meal was significantly higher than that in Danish fish meal $(\mathrm{P}<0.05)$. The results also showed that both contain minerals and calcium and phosphorus level was higher in clupeids fish meal than Danish fish meal. It was concluded that clupeids fish showed possibility of replacing Danish fish meal in fish diets on a ratio 1:1 basis and such will be confirmed in a feeding experiment. The success of clupeids replacing foreign fish meal will help the West Africa region to reduce importation.
\end{abstract}

\section{Introduction}

Fish is one of the most important sources of animal protein available in the tropics and has been widely accepted as a good source of protein and other elements for the maintenance of healthy body [1] for the populace. Substantial percentage of the protein needs of the population of the villages and towns is supplied through fishing in several Nigerian communities [2]. The less developed countries capture $50 \%$ of the world fish harvest and a large proportion of the catch are consumed internally [3]. In Asian countries over 50\% of the animal protein intakes comes from fish while in Africa; the proportion is $17.50 \%$ [4]. In Nigeria fish constitute $40 \%$ of the animal protein intake [5]. To boost availability of fish and its intake aquaculture development has been encouraged in recent times as capture fisheries supply continues to decline. However, the success of aquaculture production is largely dependent on fish feed supply and feed production requires fish meal.

Fishmeal is an essential component of fish feed and it is important for good growth of fish thereby leading to a profitable output in fish production. A large quantity of fishmeal used for feed in Nigeria and West African Region is imported and it is very expensive. Small quantity of local fishmeal is available in the market. They are poor in quality, produced from trash fish, heads and crumbs gathered from fish sellers. Sixty to seventy (60-70) \% cost of a kilogram of fish feed is borne by fishmeal, so lowering the cost of fishmeal will reduce the unit cost of fish feed by $20 \%$. Research work on replacement of some quantities of fishmeal in feed formulation with soybean [6], poultry feather meal [7] live maggot [8], Moringa oleifera leaves [9] and some other by-products has only succeeded in reducing the level of inclusion. There is need for a local source of fishmeal to totally replace the amount of foreign fish meal required to impact palatability, acceptability, enticing aroma, good growth performance on the fish feed for fish production. Lantern fish (a deep-sea fish) is abundant in our coastal water and are yet to be exploited which can be assessed by the Nigerian Institute of Oceanography. Also, the clupeids fish produce abundantly in the Nigerian freshwater bodies and are yet to be totally exploited. The nutritional composition of fish varies greatly from one species and individual to another, depending on age, feed intake, sex and sexual changes connected with spawning, the environment and season [10]. There is dearth of information on good quality local fishmeal availability in Nigeria and West Africa in general. This necessitates the initiation of the project on local fishmeal development from clupeid and lantern fish which seems very suitable for the purpose if harnessed. This particular work is to harness the advantage of abundance and prolificacy of clupeids fish species to produce local fish meal and reduce the importation of fish meal. Fish feed will be cheaper, employment generated, more fish produced, farmers income increased and aquaculture production to National GDP will improve.

\section{Material and method}

Danish fish meal was procured from feed ingredients marketers at Lagos. Clupeids fish caught by fishermen with a trawl net of $3 \mathrm{~mm}$ -

${ }^{\star}$ Correspondence to: Ibiyo LMO, Fish Nutrition and Health Programme, National Institute for Freshwater Fisheries Research, PMB, New Bussa, Niger State, Nigeria, Tel: 08059241879; E-mail: oniviemercy@yahoo.com

Key words: clupeids fish meal, danish fish meal, nutrient composition

Received: November 12, 2018; Accepted: November 23, 2018; Published: November 26, 2018 
codend-mesh size from in Kainji Dam basin was procured. The caught population comprises of the two species of clupeids namely; Pellonula afzeluisi and Sierrathrissa leonensis [11]. The sample was processed by sun drying on a rack of mosquito wire net supported by wooden framwhich is the common method adopted by the fishers of clupeids fish. Effort was not made to separate the fish into the species group because the fishermen will always fish both and process them together and bagged same. It was a deliberate to assess what will eventually be available to fish farmers or feed producers. The sun-dried sample was milled and taken for some nutritional analysis which comprised of proximate composition, amino acid profile, mineral content and fatty acids analysis.

The analyses of clupeids fish meal were carried out by University of Ilorin Analytical Laboratory under the supervision of the collaborating staff (D r. R.M.O. Kayode). Proximate composition was measured following the procedures of [12]. Nitrogen was measured following the micro-Kjeldahl methods and multiplied by 6.25 to estimate crude protein content.

\section{Amino acids analysis}

Amino acids were measured after acid hydrolysis of protein using the Pico Tag method and high-pressure liquid chromatography (HPLC). Sulphur amino acids (Cysteine or methionine) were measured separately using similar methods after oxidation with performic acid.

\section{Mineral analysis}

The digested sample was sub-sampled into pre-cleaned borosilicate glass containers for Atomic Absorption Spectrophotometer analysis. Standards of Iron, Copper, Cobalt, Zinc, Selenium, Calcium, Magnesium, Potassium, Manganese, Nickel, Molybdenum and Sodium solutions of $0.2,0.4,0.6,0.8$ and $1.0 \mathrm{mg} / \mathrm{l}$ were made from each of the heavy metals solution of $1000 \mathrm{mg} / \mathrm{l}$ stock solutions of the analytes. The set of standard solutions and the filtrate of the digested samples were analysed by AAS. The detection limit of the metals in the sample was $0.0001 \mathrm{mg} / \mathrm{l}$ by means of the UNICAM 929 London, Atomic Absorption Spectrophotometer powered by the SOLAAR software. Iron, Copper, Cobalt, Zinc, Selenium, Calcium, Magnesium, Potassium, Manganese, Nickel, Molybdenum and Sodium, cathode lamps were used for the analysis of the respective mineral ions in the standards and the filtrate of the samples. Gas mixtures were used in the generation of the flame.

\section{Phosphorus}

The sample was digested with nitric acid. The content was boiled within a minute to ensure a complete conversion of phosphorus pentoxide to orthophosphate. The solution was allowed to pass through the resin packed column of $10 \mathrm{~cm}$ and the filtrate was collected in a $10 \mathrm{ml}$ pyrex test tube. $2.0 \mathrm{ml}$ of the colour development reagent was added. The absorbance of both standard and the sample were measured at $650 \mathrm{~nm}$.

\section{Statistical analysis}

The data obtained were subjected to student T-test of significance after which values were represented in graphs.

\section{Result}

\section{Chemical analysis of reference and test ingredients}

Proximate composition: The results of proximate composition analysis of the reference (Danish fish meal) and the test (Clupeids fish meal) ingredients are presented in Figure 1. The clupeids' crude protein content (C.P.) $70.68 \%$ is not significantly different from that of Danish fish meal (imported fish meal) which is $72.60 \%$ C.P. $(\mathrm{P}<0.05)$. Large portion of the lipids in clupeids fish is majorly under the skin with some in the peritoneum.

Amino acid profile of clupeids and danish fish meals: Figure 2 showed the amino acids' profile of the two (2) fish meals. The values of amino acids of both are not far from each other. However, the sulphur amino acids (methionine and cysteine) values are higher in clupeids fish meal than in Danish fish meal despite the limiting nature of these amino acids.

Mineral composition of clupeids and danish fish meals: The mineral composition showed in Figure 3, indicated higher quantities of phosphorus and potassium for clupeids fish meal.

\section{Discussion}

Generally, the analytical results showed an indication of the clupeids fish meal being able to replace the foreign fish meal in fish feed on a ratio of 1:1. This will be confirmed by the results of the feeding experiments. The lipid content from the proximate composition is higher than $1.32 \%$ and 1.04 respectively reported for adult and fingerlings of Clarias gariepinus [13] and within the range of 1.2 to 10.8 reported for salmo trutta by Murray and Burt [14].

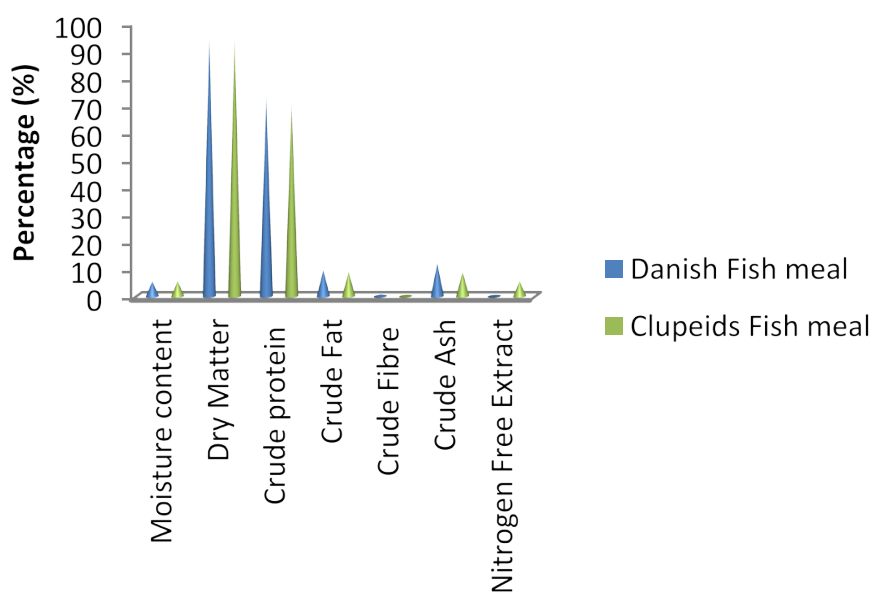

Figure 1. Proximate Composition of Danish fish meal and Clupeids Fish meal

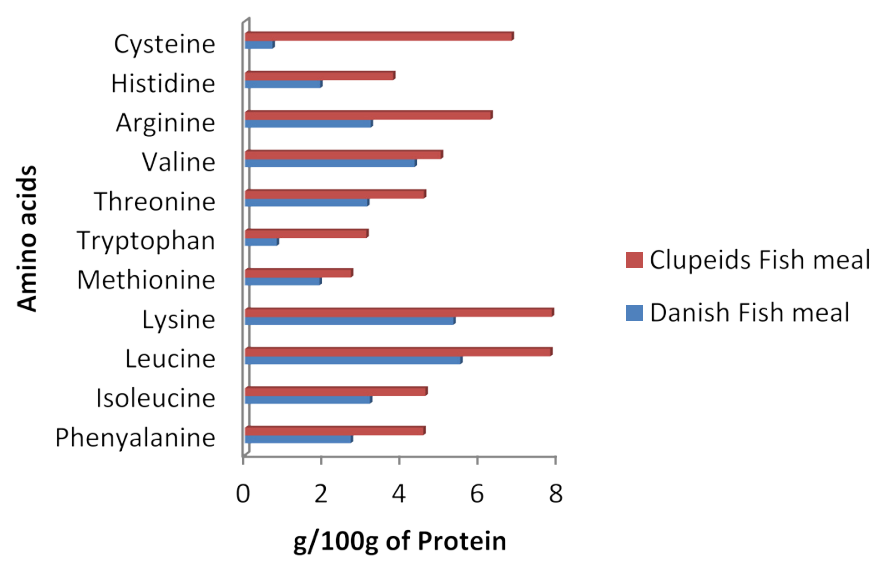

Figure 2. Amino acid composition of Danish fish meal and Clupeids Fish meal 


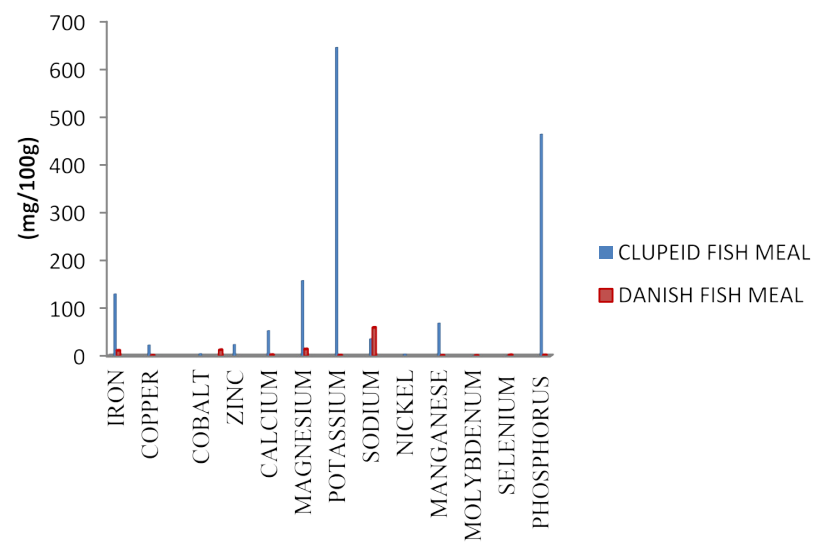

Figure 3. Mineral Compositions of Danish and Clupeids Fish meals

It can be concluded from the results of the studies that clupeids fish meal is an important local resource that can totally replace the foreign fish meal in feed production in Nigeria and West Africa sub-region due to the fact that it has a well balance nutrient composition. It will be necessary to invest in stocking the water bodies where they are not presently available for accessibility and availability to the fish farmers all over the country and West Africa sub-region.

\section{References}

1. Andrew AE (2001) Fish - Processing Technology, University of Ilorin Press Nigeria 7-8.

2. Ako PA, Salihu SO (2004) Studies on some major and trace metals in smoked and oven - dried fish. J Appl Sci Environ Manage 8: 5-9.
3. FAO (1985) World catch and trade of fisheries and products in 1984.Info fish marketing Digest No 25.

4. William CF, Dennis CW (1988) Food Microbiology, 4th edition, Food Science series. MacGraw-Hill Book Company, Singapore, 243-252.

5. Olatunde AA (1998) Approach to the study of Fisheries Biology in Nigeria inland water. Proceedings of Internatioanl Conference of two decades of Research in Lake Kainji 338-541.

6. Eyo AA (1990) Some aspects of utilization of soybean meal by young mudfish, Clarias anguillaris Linnaeus. Ph.D. Dissertation, Ahmadu Bello University, Zaria, Nigeria $401 \mathrm{pp}$.

7. Ojewole GS, Annah SI (2006) Nutritive value of Danish fish meal, crayfish dust meal and shrimp waste meal inclusion in Broiler diets. Intern J Poultry Sci 5: 390-394.

8. Madu CT, Ufodike (2000) Growth and survival of catfish (Clarias gariepinus) juvenile fed live tilapia and maggot as unconventional diets. J Aqua Sci18.

9. Ritcher N, Siddhuraju A, Becker K (2003) Evaluation of nutritional quality of Moringa (Moringa oleifera Lam.) leaves as alternative protein source for Tilapia (Oreochromis niloticus L.). Aquaculture 217: 599-611.

10. Silva JJ, Chamul RS (2000) Composition of marine and fresh water finfish and shellfish species and their products. In: RE Martin, EP Carter, EJ Flick and LM Davis (Eds.), Marine and fresh water products handbook, Lancaster, Pennsylvania, U.S.A: Technomic Publishing Company 31-46.

11. Eyo AA (1988) Studies on the Biochemical composition of Clupeids: Pellonula afzeluisi (Johnces 1954) and Serrathrissa leonensis (Thys Verden Andenaerde 1959). Annu Rep National Insti of Freshwater Fisheries Res 145-148.

12. AOAC (2000) Association of Official Analytical Chemists. 17th Edition, Washington D.C.., U.S.A 14,47 .

13. Ayinla OA (1993) Chemical composition of Clarias gariepinus collected from the wild African Regional Aquaculture Center, Nigerian Institute of Oceanography and Marine Research, Port - Harcourt, Nigeria. Technical Papers No. 86 12p.

14. Murray J, Burt TR (1969) The composition of fish Torry Advis Note, Abberdeen, Scottland 38p.

Copyright: $\left(\mathbb{C}_{2018}\right.$ Ibiyo LMO. This is an open-access article distributed under the terms of the Creative Commons Attribution License, which permits unrestricted use, distribution, and reproduction in any medium, provided the original author and source are credited. 